\title{
Integrated Management Strategies for Phytophthora sojae Combining Host Resistance and Seed Treatments
}

A. E. Dorrance, Department of Plant Pathology, The Ohio State University, OARDC, Wooster 44691; A. E. Robertson and S. Cianzo, Department of Plant Pathology, Iowa State University, Ames 50011-1020; L. J. Giesler, Department of Plant Pathology, University of Nebraska, Lincoln 68583; C. R. Grau, Department of Plant Pathology, University of Wisconsin-Madison, Madison 53706-1598; M. A. Draper, formerly Plant Science Department, South Dakota State University, Brookings 57007-1090; A. U. Tenuta, Ontario Ministry of Agriculture, Food and Rural Affairs, Ridgetown, Ontario, Canada, NOL 2C0; and T. R. Anderson, Agriculture and Agri-Food Canada, Harrow, Ontario, Canada, NOR 1G0

\begin{abstract}
Dorrance, A. E., Robertson, A. E., Cianzo, S., Giesler, L. J., Grau, C. R., Draper, M. A., Tenuta, A. U., and Anderson, T. R. 2009. Integrated management strategies for Phytophthora sojae combining host resistance and seed treatments. Plant Dis. 93:875-882.

Phytophthora sojae has re-emerged as a serious soybean pathogen in the past decade. This may be due in part to changes in resistance levels in current cultivars, adoption of $P$. sojae populations to deployed Rps genes, and highly favorable environments in the past decade. This multilocation study evaluated the effect of seed treatments on the incidence and severity of Phytophthora root and stem rot on soybeans with different combinations of Rps genes and levels of partial resistance. The efficacy of the seed treatments was highly variable across locations. Seed treatments (metalaxyl and mefenoxam) provided protection and increased yields across cultivars in locations where rain or irrigation occurred shortly after planting (Ohio, South Dakota, and Ontario). However, there were no significant differences in stand or yield consistently across cultivars in Iowa, Nebraska, Wisconsin, or Ohio, where heavy precipitation did not occur until later growth stages. The environment, levels of inoculum, and pathogen complex may have played a role in the different responses to the seed treatments and to the different combinations of Rps genes and levels of partial resistance to P. sojae in the cultivars. Fields that are poorly drained and have $P$. sojae populations with complex pathotypes may benefit the most from seed treatments. Individual fields where producers may see the greatest benefit to utilizing these integrated management strategies will need to be identified.
\end{abstract}

Phytophthora sojae (Kaufm. \& Gerd.) is a limiting factor in soybean (Glycine max (L.) Merr.) production in more fields now than it was 50 years ago, when it was first recognized as a soybean pathogen (20,22,23). Losses from Phytophthora root and stem rot caused by $P$. sojae can occur anytime during the production season. Early-season infections reduce stands and necessitate replanting, while later season infections can cause plant mortality, which impacts final stands, and reductions in root health and thus yield. Disease incidence and severity are highest in fields with slow drainage or where periodic saturated soil conditions occur. Increased frequency of virulence in $P$. sojae populations to widely deployed resistance genes $(R p s)$, a reduction in levels of partial resistance in recently released commercial cultivars,

Corresponding author: A. E. Dorrance

E-mail: dorrance.1@osu.edu

Accepted for publication 12 May 2009.

doi:10.1094/PDIS-93-9-0875

(C) 2009 The American Phytopathological Society shorter rotations, and highly favorable weather patterns for disease development during spring all may have contributed to an increase in incidence of Phytophthora root and stem rot during the past decade $(1,11,14-18)$. Therefore, an integrated approach to reducing these losses is now required.

Several integrated management strategies were proposed by Schmitthenner (20) to manage this soilborne pathogen. The first strategy described was to combine the use of metalaxyl soil treatment (applying fungicide in-furrow) during planting with cultivars with high levels of partial resistance (tolerance). The second was to plant cultivars with high levels of partial resistance in fields that were tilled, had good tile drainage, crop rotation, and metalaxyl seed treatment. Several of these management strategies are no longer options due to changes in soybean production practices, soil conservation, and wetlands preservation demands that occurred in the past two decades since these proposals were first made. Application of metalaxyl infurrow is limited by widespread adoption of conservation tillage or reduced tillage, narrow row-widths (17.8 to $38.1 \mathrm{~cm}$ versus
$76.2 \mathrm{~cm}$ previously), and a shift to planting with grain drills, which makes in-furrow applications difficult. Furthermore, planting in narrow rows increases the amount and cost of fungicide required for each field. When soybean prices are low, as they were during the late 1990s, this type of application is cost prohibitive.

Conservation or reduced tillage production systems are widely adopted throughout the north-central region of the United States and Ontario, Canada. While this production practice conserves soil, it also favors some plant pathogens including $P$. sojae. Workneh et al. (22) were able to recover $P$. sojae more frequently from soil collected from fields in Illinois, Minnesota, Missouri, and Ohio managed with conservation tillage than from conventional tillage fields. The cropping rotation has also changed as a result of wheat and forage production declining during the late 1980 s to early 1990s. Consequently, in some areas of the north-central region, a rotation of corn and soybeans with soybeans planted, at times, 2 to 5 years in a row predominates. In addition, the amount of tile that can be placed in a field to assist with drainage is restricted in some areas (M. Draper, South Dakota, personal observation), while in other regions antiquated tile systems need replacing (A. Dorrance, Ohio, personal observation). The reduced capacity to drain excess water from some fields may have also contributed to the increased prevalence of $P$. sojae. Another development in the past decade was the widespread introduction of soybean cultivars with resistance to glyphosate. Although many of these cultivars released early in this germplasm shift did have Rps genes (such as Rps1a), some were ineffective and many did not carry high levels of partial resistance to $P$. sojae (2-4). Measures of the level of partial resistance were collected throughout this germplasm shift, and dramatic differences among the entries for this trait were observed (2-4; Fig. 1).

Increasing genetic diversity in endemic $P$. sojae populations has also been observed $(1,11,14-18)$. Partial resistance to $P$. sojae in soybeans provides protection against all pathotypes. Cultivars that ex- 


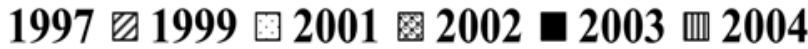

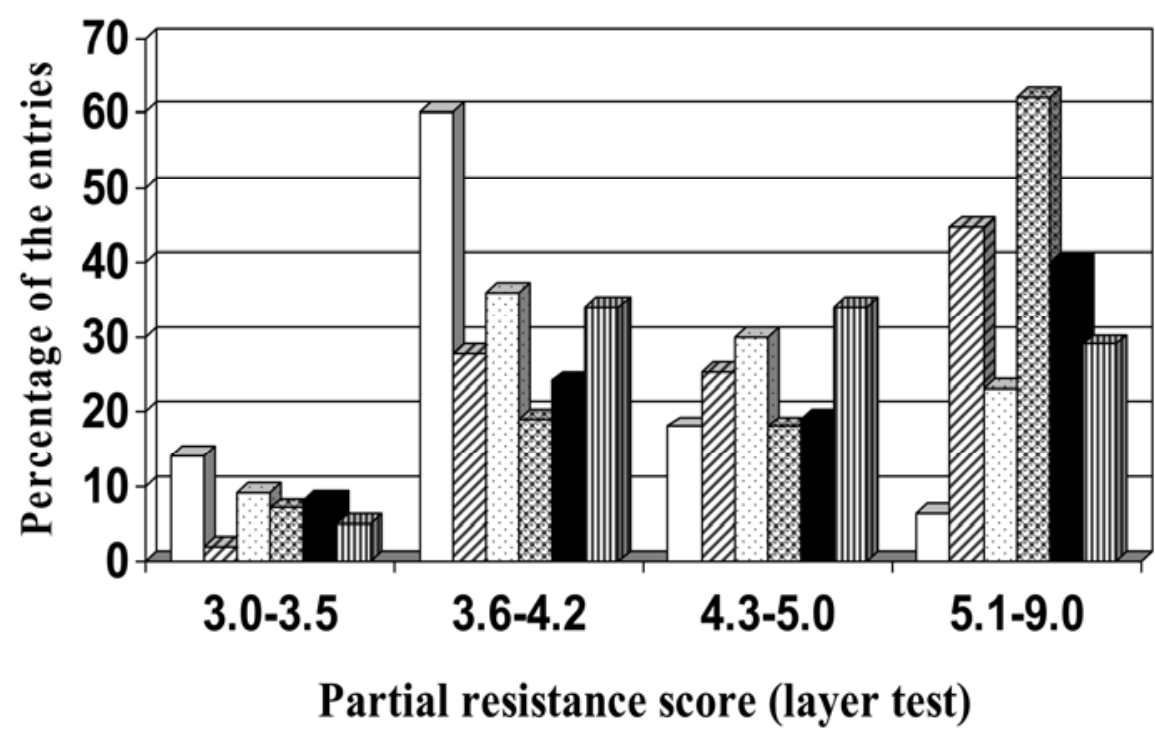

Fig. 1. Comparison of partial resistance levels in soybean cultivars entered in the Ohio State University Performance Trials from 1997 to 2004. All entries were evaluated in a layer cup test, and 3 indicates high levels of partial of resistance with $1 / 3$ of the roots rotted; 5 indicates most roots rotted; and 9 indicates that plants are dead. Data were summarized from annual reports (2-4).

Table 1. A list of soybean cultivars, Rps gene(s), partial resistance level, and state or province that were used to evaluate integrated management strategies for Phytophthora sojae in the United States and Ontario, Canada

\begin{tabular}{|c|c|c|c|}
\hline Cultivar $^{\mathrm{a}}$ & Rps gene(s) & $\begin{array}{l}\text { Level of partial } \\
\text { resistance }^{b}\end{array}$ & State \\
\hline Conrad & $r p s$ & High & Ohio, Ontario \\
\hline Cult A & $R p s 1 \mathrm{k}$ & Low & Ohio \\
\hline General & Rps $1 \mathrm{k}$ & High & Ohio \\
\hline Kottman & $R p s 1 \mathrm{k}$ plus $R p s 3 \mathrm{a}$ & High & Ohio \\
\hline OX20-8 & Rps $1 \mathrm{a}$ & None & Ontario \\
\hline Sandusky & $\operatorname{Rps} 1 \mathrm{k}$ & Moderate & Ohio \\
\hline Sloan & rps & Low & Ohio, Iowa \\
\hline Archer & Rps $1 \mathrm{k}$ plus $R p s 6$ & Low & Iowa \\
\hline Williams & rps & Moderate & Iowa \\
\hline Stine2402 & rps & $\operatorname{High}(\mathrm{C})$ & Iowa \\
\hline Syngenta S27-T7 & rps & High (C) & Iowa \\
\hline $\mathrm{S} 31-\mathrm{V} 3$ & rps & Moderate & Iowa \\
\hline 2834RR & $R p s 1 \mathrm{k}$ & Low & Iowa \\
\hline Asgrow AG2703 & $\operatorname{Rps} 1 \mathrm{k}$ & Low (C) & Nebraska \\
\hline Garst 2903 RR & Rps $1 \mathrm{k}$ & High (C) & Nebraska \\
\hline Garst 3083 RR & rps & $\operatorname{High}(\mathrm{C})$ & Nebraska \\
\hline Croplan RT2440 & rps & Moderate & Wisconsin \\
\hline Sturdy & Rpsla & Low & Wisconsin \\
\hline Pioneer 92M40 & Rps1c & Moderate & Wisconsin \\
\hline NK S24-K4 & Rpsla & Moderate & Wisconsin \\
\hline Asgrow AG2403 & Rps1k & Moderate & Wisconsin \\
\hline Pioneer 91B91 & rps & Low & South Dakota \\
\hline Kaltenberg KB150RR & rps & High & South Dakota \\
\hline SD1081RR & Rps 1a & Low & South Dakota \\
\hline NK S19-V2 & $\operatorname{Rps} 1 \mathrm{a}$ & High & South Dakota \\
\hline Pioneer 91B64 & Rps 1c & Low & South Dakota \\
\hline Kaltenberg KB161RR & Rps 1c & High & South Dakota \\
\hline Pioneer 92B05 & Rps $1 \mathrm{k}$ & Low & South Dakota \\
\hline Kaltenberg KB172R & $\operatorname{Rps} 1 \mathrm{k}$ & High & South Dakota \\
\hline Harovinton & Rps 1c & Moderate & Ontario \\
\hline Amsoy71 & Rps1c & Low & Ontario \\
\hline Elgin87 & $\operatorname{Rps} 1 \mathrm{k}$ & High & Ontario \\
\hline
\end{tabular}

${ }^{a}$ Both public and commercial cultivars were used in these studies. Seed of public cultivars were available at the Ohio State University.

b Partial resistance levels that were verified were determined through a greenhouse layer test in which none indicates 90 to $100 \%$ kill of all seedlings; low indicates that roots are all colonized and 50 to $89 \%$ of the seedlings are killed; moderate indicates that all seedlings survived but roots are 40 to $70 \%$ colonized; and high indicates that all seedlings survive and 10 to $39 \%$ of roots are colonized. Values followed by $(\mathrm{C})$ indicate the seed companies rating for this trait. press high levels of partial resistance have the most consistent yield across locations (12) and do not select for $P$. sojae pathotypes that can adapt to single-gene resistance. However, a caveat of partial resistance is that it is not expressed in seeds and germinating seedlings (10). Thus, cultivars with this type of resistance are still highly susceptible to infection by $P$. sojae at least until the unifoliate leaves are visible (5 to 14 days after planting depending on soil temperatures).

Incidence and severity of Phytophthora root and stem rot have increased in the region; thus, we evaluated several management strategies that producers could implement in the changing production landscape. While metalaxyl and mefenoxam are not economically viable as infurrow treatments, seed treatment applications may provide sufficient protection against early-season damping-off. Dorrance and McClure (10) proposed that high rates of these active ingredients were required to protect seedlings from infection based on greenhouse studies. However, a widespread assessment of these higher rates has not been completed in the field nor with the different resistance "packages" currently available in soybean cultivars. Therefore, the objective for this study was to evaluate the effect of the addition of a seed treatment on soybean cultivars with Rps genes with or without high levels of partial resistance. The development of Phytophthora root and stem rot is very dependent on soil moisture, thus this study was evaluated across the north-central region in six states in the United States and Ontario, Canada during 2003 to 2006.

\section{MATERIALS AND METHODS}

Plant material. A total of 32 soybean cultivars from both public and private seed companies were selected based on their maturity group, adaptation to local environments, and resistance to $P$. sojae (Table 1). Cultivars had different resistance combinations of Rps genes plus low or high levels of partial resistance. In some cases, seed company data were used for the resistance descriptions, while for others the presence of Rps genes was verified through a series of inoculations with known pathotypes (races) of $P$. sojae using the hypocotyl technique $(8,21)$. Partial resistance levels from seed companies was also used, while a few were verified with the layer test (21) in which soybeans are planted in cups $2.5 \mathrm{~cm}$ above an agar layer colonized by $P$. sojae. The plants were scored 3 weeks after planting, and a 3 indicates high levels of partial of resistance with $1 / 3$ of the roots rotted, 5 is most roots rotted, and 9 indicates that the plants are dead.

Seed treatments. The effect of seed treatment on the incidence and severity of Phytophthora root rot was studied on the test cultivars. Seed treatments included 
metalaxyl (Allegiance; Bayer Crop Science, Research Triangle Park, NC) at 0.94 $\mathrm{g}$ a.i./kg seed; mefenoxam (Apron XL, Syngenta Crop Protection, Inc., Greensboro, $\mathrm{NC}$ ) at $15.0 \mathrm{~g}$ a.i./100 $\mathrm{kg}$ seed; mefenoxam at $3.75 \mathrm{~g}$ a.i. $/ 100 \mathrm{~kg}$ plus fludioxonil at $2.5 \mathrm{~g}$ a.i./100 $\mathrm{kg}$ seed (Apron Maxx, Syngenta); or the combination of mefenoxam at $3.75 \mathrm{~g}$ a.i./100 kg plus fludioxonil at $2.5 \mathrm{~g}$ a.i./100 kg plus mefenoxam at $11.25 \mathrm{~g}$ a.i./100 $\mathrm{kg}$ seed (Apron Maxx plus Apron XL, Syngenta). Seed treatments were applied as a slurry at a rate of $237 \mathrm{ml} / 45.4 \mathrm{~kg}$.

Study locations. Treatments were evaluated in fields with long-term histories of Phytophthora root rot in Iowa during 2005 and 2006, Ohio during 2005 and 2006, Nebraska during 2004 and 2005, South Dakota during 2003, Wisconsin during 2006, and Ontario, Canada during 2004 (Table 2). Specifics for each location are listed for each state below.

Iowa. Field studies were planted on 19 May 2005 on commercial farms near Eddyville, and on 26 and 29 May 2006 at the Albion and Albert City fields, respectively. Each location has numerous pathotypes of $P$. sojae and is poorly drained with greater than $22 \%$ clay. The study was arranged in a split-plot design with cultivar as the whole plot and the seed treatments as the subplots. Each experimental unit was $6.1 \mathrm{~m}$ long and $3 \mathrm{~m}$ wide with four rows spaced $76 \mathrm{~cm}$ apart. Approximately 33 seeds were planted per meter length of row. There were six cultivars (Table 1) and two seed treatments: a combination of mefenoxam, $11.25 \mathrm{~g}$ a.i./100 $\mathrm{kg}$ of seed (Apron $\mathrm{XL}$ ), plus mefenoxam, $3.75 \mathrm{~g}$ a.i., and fludioxonil, $2.5 \mathrm{~g}$ a.i./100 $\mathrm{kg}$ seed (Apron Maxx RTA); or mefenoxam, 15.0 g a.i./100 $\mathrm{kg}$ of seed (Apron XL). Nontreated seed of each cultivar was planted as a control. The number of soybean plants was recorded in a 2-m section within the center two rows of each plot approximately 3 weeks after planting and immediately prior to harvest. Phytophthora stem rot incidence was assessed throughout the growing season 7 to 10 days after a heavy rain $(>2.5 \mathrm{~cm})$ for a total of three evaluations. Disease incidence was calculated as the percentage of plants showing stem rot symptoms from the initial stand count. Yield data were collected at maturity by harvesting $4 \mathrm{~m}$ from each of the center two rows of each plot and adjusted to $13 \%$ moisture.

Nebraska. Field studies were planted on 6 May near Herman in 2004 and 27 May

Table 2. Characteristics of study locations used for evaluation of integrated pest management strategies for Phytophthora seedling blight and root and stem rot of soybean caused by Phytophthora sojae

\begin{tabular}{|c|c|c|c|c|c|c|c|c|c|c|c|}
\hline \multirow{3}{*}{$\begin{array}{l}\text { Characteristic } \\
\text { Location/ } \\
\text { year } \\
\text { Soil type }\end{array}$} & \multicolumn{3}{|c|}{ Iowa } & \multicolumn{2}{|c|}{ Nebraska } & \multicolumn{3}{|c|}{ Ohio } & \multirow{2}{*}{$\begin{array}{c}\begin{array}{c}\text { South } \\
\text { Dakota }\end{array} \\
\text { Groton } \\
2003\end{array}$} & \multirow{2}{*}{$\begin{array}{c}\begin{array}{c}\text { Ontario, } \\
\text { Canada }\end{array} \\
\text { Harrow } \\
2004\end{array}$} & \multirow{2}{*}{$\begin{array}{c}\text { Wisconsin } \\
\begin{array}{c}\text { Racine } \\
2006\end{array}\end{array}$} \\
\hline & $\begin{array}{c}\text { Eddyville } \\
2005\end{array}$ & $\begin{array}{c}\text { Albert City } \\
2006\end{array}$ & $\begin{array}{c}\text { Albion } \\
2006\end{array}$ & $\begin{array}{c}\text { Tekamah } \\
2005\end{array}$ & $\begin{array}{c}\text { Herman } \\
2004\end{array}$ & $\begin{array}{l}\text { Custar } \\
2005\end{array}$ & $\begin{array}{l}\text { Custar } \\
2005\end{array}$ & $\begin{array}{l}\text { Custar } \\
2006\end{array}$ & & & \\
\hline & $\begin{array}{l}\text { Pershing } \\
\text { silt loam/ } \\
\text { Douds } \\
\text { loam }\end{array}$ & $\begin{array}{l}\text { Canisteo } \\
\text { clay loam/ } \\
\text { Nicollet } \\
\text { loam }\end{array}$ & $\begin{array}{l}\text { Muscatine } \\
\text { silty clay } \\
\text { loam/Garwin } \\
\text { silty clay loam }\end{array}$ & $\begin{array}{l}\text { Luton } \\
\text { silty clay }\end{array}$ & $\begin{array}{l}\text { Butler silt } \\
\text { loam }\end{array}$ & \multicolumn{3}{|c|}{ Hoyteville clay } & Silt loam & $\begin{array}{l}\text { Brookston } \\
\text { silty clay } \\
\text { loam }\end{array}$ & \\
\hline Percent clay & 23-24 & 22-29 & $28-32$ & 60 & 50 & & 35 & & $18-45$ & 30 & 30 \\
\hline Drainage & $\begin{array}{l}\text { Poor to } \\
\text { moderate }\end{array}$ & Poor & Poor & Poor & Poor & & Poor & & Poor & Poor & Moderate \\
\hline $\begin{array}{l}\text { Rainfall } 10 \\
\operatorname{DAP}^{\mathrm{a}}(\mathrm{cm})\end{array}$ & 0.6 & 0 & 3.6 & 6.63 & 3.33 & 2.5 & 1.6 & 8.0 & $9.9^{\mathrm{b}}$ & 6.7 & 3.8 \\
\hline $\begin{array}{l}\text { Irrigation } 10 \\
\text { DAPa }^{a}(\mathrm{~cm})\end{array}$ & 0 & 0 & 0 & 0 & 0 & 7.5 & & 5.3 & 0 & & 0 \\
\hline $\begin{array}{l}\text { Mean temp } 10 \\
\operatorname{DAP}^{\mathrm{a}}(\mathrm{C})\end{array}$ & 16.8 & 23.5 & 22.4 & 18.2 & 17.6 & 14.4 & 24.2 & 21.6 & $14.4-31.7$ & 23.9 & 13.0 \\
\hline $\begin{array}{l}\text { Total rainfall/ } \\
\text { season }(\mathrm{cm})\end{array}$ & 31.6 & 40.9 & 45.7 & 21.4 & 29.6 & 42.7 & & 51.1 & 53.3 & 34.7 & 35.8 \\
\hline$P$. sojae race & Many & Many & Many & $\begin{array}{c}25(1 \mathrm{a}, 1 \mathrm{~b}, \\
1 \mathrm{c}, 1 \mathrm{k}, 7)\end{array}$ & $\begin{array}{c}28(1 \mathrm{a}, 1 \mathrm{~b} \\
1 \mathrm{k}, 7)\end{array}$ & & Many & & $\begin{array}{l}1,3,4,25(1 \mathrm{a}, \\
1 \mathrm{~b}, 1 \mathrm{c}, 1 \mathrm{k}, 7)\end{array}$ & Many & $3(1 \mathrm{a}, 7)$ \\
\hline
\end{tabular}

${ }^{a} \mathrm{DAP}=$ days after planting.

b $9.4 \mathrm{~cm}$ of rain was received within 20 DAP in South Dakota during 2003. Plants were just at the VC stage.

Table 3. Comparison of stand counts and yield of soybean cultivars with different resistance combinations to Phytophthora sojae and seed treated with mefenoxam, $11.25 \mathrm{~g}$ a.i./100 $\mathrm{kg}$ (Apron XL), or nontreated in Ohio during 2005 and 2006

\begin{tabular}{|c|c|c|c|c|c|c|c|}
\hline \multirow[b]{2}{*}{ Cultivar (C) } & \multirow[b]{2}{*}{ Seed treatment $(T)$} & \multicolumn{2}{|c|}{ Irrigated at V1 2005} & \multicolumn{2}{|c|}{ Irrigated at planting 2005} & \multicolumn{2}{|c|}{ Irrigated at planting 2006} \\
\hline & & Final stand $^{\mathrm{a}}$ & Yield $^{b}$ & Final stand & Yield & Final stand & Yield \\
\hline \multirow[t]{2}{*}{ Sloan } & Nontreated & 9.8 & $2,419.2$ & 5.0 & $1,223.0$ & 6.4 & $1,868.2$ \\
\hline & ApronXL & 11.5 & $2,298.2$ & 6.2 & $1,357.4$ & 8.0 & $2,466.2$ \\
\hline \multirow[t]{2}{*}{ Conrad } & Nontreated & 13.7 & $2,856.0$ & 10.3 & $2,076.5$ & 6.8 & $2,197.4$ \\
\hline & ApronXL & 14.0 & $3,010.6$ & 9.2 & $2,016.0$ & 9.7 & $2,748.5$ \\
\hline \multirow[t]{2}{*}{ Cult A } & Nontreated & 12.8 & $2,493.1$ & 5.9 & $1,014.7$ & 7.3 & $2,278.1$ \\
\hline & ApronXL & 12.6 & $2,667.8$ & 8.6 & $1,532.2$ & 14.5 & $2,936.6$ \\
\hline \multirow[t]{2}{*}{ General } & Nontreated & 15.6 & $3,313.0$ & 8.6 & $2,573.8$ & 12.3 & $3,373.4$ \\
\hline & ApronXL & 14.1 & $3,386.9$ & 12.1 & $2,956.8$ & 15.6 & $3,487.7$ \\
\hline \multirow[t]{2}{*}{ Sandusky } & Nontreated & 13.0 & $3,259.2$ & 6.6 & $2,137.0$ & 13.2 & $3,138.2$ \\
\hline & ApronXL & 14.1 & $3,259.3$ & 8.3 & $2,607.4$ & 11.2 & $3,218.9$ \\
\hline \multirow[t]{2}{*}{ Kottman } & Nontreated & 14.9 & $3,595.2$ & 11.4 & $2,802.2$ & 10.7 & $3,010.6$ \\
\hline & ApronXL & 14.1 & $3,702.7$ & 10.3 & $2,600.6$ & 10.9 & $3,400.3$ \\
\hline \multirow[t]{2}{*}{ Means } & Nontreated & 13.2 & $3,003.8$ & 7.9 & $1,975.7$ & 9.5 & $2,627.5$ \\
\hline & Apron XL & 13.4 & $3,057.6$ & 9.0 & $2,177.3$ & 11.6 & $3,050.9$ \\
\hline $\operatorname{LSD}^{\mathrm{c}}(P \leq 0.05) \mathrm{C}$ & & $2.1 * *$ & $2.1 * *$ & NS & $3.9 * *$ & $3.1 * *$ & $3.6^{*}$ \\
\hline $\operatorname{LSD}(P<0.05) \mathrm{T}$ & & NS & NS & $1.0 *$ & $3.1 * *$ & $1.8^{*}$ & $7.5^{* *}$ \\
\hline $\operatorname{LSD}(P \leq 0.05) \mathrm{C} \times \mathrm{T}$ & & NS & NS & $1.7^{*}$ & $3.7^{*}$ & NS & NS \\
\hline
\end{tabular}

a Plants per meter.

${ }^{\mathrm{b}} \mathrm{kg} / \mathrm{ha}$. Adjusted to $13 \%$ moisture.

${ }^{\mathrm{c}}$ Fisher's protected least significant difference, $* *$ indicates $P<0.01$, and $*$ indicates $P<0.05$. 
near Tekamah in 2005 on commercial farms. Both fields had a history of Phytophthora root rot with $P$. sojae race 25 (vir $1 \mathrm{a}, 1 \mathrm{~b}, 1 \mathrm{c}, 1 \mathrm{k}, 7)$, which was recovered the year prior to the study. The soil type for each field was a Luton silty clay and a Butler silt loam for Tekamah and Herman, respectively. In 2004, the plots were $401 \mathrm{~m}$
Table 4. Comparison of soybean cultivars with different resistance combinations to Phytophthora sojae and seed nontreated and treated with metalaxyl (Allegiance $0.94 \mathrm{~g} / \mathrm{kg}[1.5 \mathrm{fl} \mathrm{oz} / \mathrm{cwt}]$ in Groton, SD during 2003

\begin{tabular}{|c|c|c|c|}
\hline Cultivar (C) & $\begin{array}{l}\text { Seed treatment } \\
\text { (T) }\end{array}$ & $\underset{(\text { plants } / \mathbf{m})^{\mathrm{a}}}{\text { Stand }}$ & $\underset{(\mathrm{kg} / \mathrm{ha})^{\mathbf{b}}}{\text { Yield }}$ \\
\hline \multirow[t]{2}{*}{ Pioneer 91B91 } & Nontreated & 18.1 & $2,997.1$ \\
\hline & Allegiance & 21.0 & $3,436.6$ \\
\hline \multirow[t]{2}{*}{ Kaltenberg KB153RR } & Nontreated & 22.5 & $3,470.9$ \\
\hline & Allegiance & 22.9 & $3,555.6$ \\
\hline \multirow[t]{2}{*}{ SD1081RR } & Nontreated & 10.4 & 975.7 \\
\hline & Allegiance & 21.7 & $2,427.9$ \\
\hline \multirow[t]{2}{*}{ NK S19-V2 } & Nontreated & 21.2 & $2,326.5$ \\
\hline & Allegiance & 24.6 & $2,173.9$ \\
\hline \multirow[t]{2}{*}{ Pioneer 91B64 } & Nontreated & 21.5 & $3,240.4$ \\
\hline & Allegiance & 25.2 & $3,214.2$ \\
\hline \multirow[t]{2}{*}{ Kaltenberg KB161RR } & Nontreated & 18.8 & $2,645.7$ \\
\hline & Allegiance & 24.4 & $3,210.1$ \\
\hline \multirow[t]{2}{*}{ Pioneer 92B05 } & Nontreated & 30.4 & $3,567.0$ \\
\hline & Allegiance & 27.5 & $3,565.6$ \\
\hline \multirow[t]{2}{*}{ Kaltenberg KB172RR } & Nontreated & 26.9 & $3,775.3$ \\
\hline & Allegiance & 27.9 & $3,824.4$ \\
\hline Nontreated & & 21.2 & $2,874.8$ \\
\hline Allegiance & & 24.4 & $3,176.0$ \\
\hline Fisher's protected $\mathrm{LSD}^{\mathrm{c}}(P \leq 0.05) \mathrm{T}$ & & $1.9^{* *}$ & $161.3^{* *}$ \\
\hline Fisher's protected LSD $(P \leq 0.05) \mathrm{C}$ & & $4.0 * *$ & $598.1^{* *}$ \\
\hline Fisher's protected LSD $(P \leq 0.05) \mathrm{C} \times \mathrm{T}$ & & $3.2 *$ & $262.1^{* *}$ \\
\hline
\end{tabular}

long with 12 rows spaced $76 \mathrm{~cm}$ apart. In 2005, the field was pivot irrigated and the plots were $800 \mathrm{~m}$ long with six rows spaced $76 \mathrm{~cm}$ apart. Three cultivars were selected and each was treated with a combination of mefenoxam, $11.25 \mathrm{~g}$ a.i./100 kg of seed (Apron XL), plus mefenoxam, 3.75 $\mathrm{g}$ a.i. and fludioxonil, $2.5 \mathrm{~g}$ a.i./100 $\mathrm{kg}$ seed (Apron Maxx RTA). The plots were arranged in a randomized complete block design with four replications of each treatment. Stand counts were collected from six 3-m lengths of row in the center two rows of each plot at the third trifoliate growth stage on 9 June and postharvest on 14 October in 2004 and at the R1 (beginning flowering) growth stage on 12 July and postharvest on 31 October in 2005 . Plots were harvested 4 October 2004 and 22 October 2005 with a combine and weigh wagon, and yield data were adjusted to $13 \%$ moisture

Ohio. The study was planted at the Ohio Agricultural Research and Development Center North West Branch Station near Custar on 18 May and 2 June 2005 and 13 June 2006 in a Hoytville clay soil. This field, which has $35 \%$ clay soil, has numerous pathotypes of $P$. sojae. Six cultivars were selected and one seed treatment, 15.0 $\mathrm{g}$ a.i./100 $\mathrm{kg}$ of seed (Apron XL), was evaluated. The study was planted in a splitplot design with the cultivars as the whole

Table 5. Effect of fungicide seed treatments mefenoxam $15.0 \mathrm{~g}$ a.i./100 $\mathrm{kg}$ of seed (Apron XL), mefenoxam, $3.75 \mathrm{~g}$ a.i. and fludioxonil, $2.5 \mathrm{~g}$ a.i./100 kg seed (Apron Maxx RTA); and mefenoxam, $11.25 \mathrm{~g}$ a.i./100 kg of seed (Apron XL) plus mefenoxam, $3.75 \mathrm{~g}$ a.i. and fludioxonil, $2.5 \mathrm{~g}$ a.i./100 kg seed (Apron Maxx RTA) on emergence, final stand, plant loss, and yield of five soybean cultivars from fields heavily infested with Phytophthora sojae in Woodslee, Ontario, in 2004

\begin{tabular}{|c|c|c|c|c|c|c|c|}
\hline \multirow[b]{2}{*}{ Cultivar (C) } & \multirow[b]{2}{*}{ Seed treatment $(T)$} & \multicolumn{3}{|c|}{ Woodslee field A } & \multicolumn{3}{|c|}{ Woodslee field B } \\
\hline & & Emergence $^{a}$ & $\begin{array}{c}\text { Final } \\
\text { stand }^{a}\end{array}$ & $\begin{array}{c}\text { Yield } \\
(\mathrm{kg} / \mathrm{ha})^{\mathrm{b}}\end{array}$ & Emergence & $\begin{array}{l}\text { Final } \\
\text { stand }\end{array}$ & $\begin{array}{c}\text { Yield } \\
\text { (kg/ha) }\end{array}$ \\
\hline \multirow[t]{4}{*}{ OX 20-8 } & Nontreated Check & 16.8 & 0.9 & 8.6 & 18.1 & 0.7 & 66.0 \\
\hline & Apron Maxx RTA & 17.6 & 1.5 & 13.1 & 17.4 & 3.2 & 90.9 \\
\hline & Apron XL & 18.5 & 2.9 & 67.4 & 18.7 & 3.3 & 291.0 \\
\hline & Apron Maxx + Apron XL & 18.8 & 3.7 & 67.10 & 17.6 & 4.4 & 284.7 \\
\hline \multirow[t]{4}{*}{ Amsoy 71} & Nontreated Check & 16.2 & 6.4 & 222.9 & 15.3 & 7.0 & 726.2 \\
\hline & Apron Maxx RTA & 16.6 & 8.4 & 697.3 & 17.5 & 10.2 & $1,341.6$ \\
\hline & Apron XL & 17.3 & 11 & 695.8 & 18.1 & 11.5 & $1,296.5$ \\
\hline & Apron Maxx RTA + Apron XL & 18.0 & 8.2 & $1,357.0$ & 16.8 & 13.2 & $1,599.7$ \\
\hline \multirow[t]{4}{*}{ Conrad } & Nontreated Check & 14.6 & 11.4 & $1,664.1$ & 17.2 & 15.2 & $2,429.8$ \\
\hline & Apron Maxx RTA & 16.9 & 16.1 & $1,582.4$ & 18.5 & 18.3 & $2,241.8$ \\
\hline & Apron XL & 17.2 & 17.0 & $2,100.0$ & 17.2 & 16.9 & $2,968.5$ \\
\hline & Apron Maxx RTA +Apron XL & 17.3 & 16.2 & $2,030.5$ & 18.5 & 17.4 & $2,879.4$ \\
\hline \multirow[t]{4}{*}{ Harovinton } & Nontreated Check & 17.3 & 13.0 & 828.3 & 17.0 & 12.5 & $1,700.5$ \\
\hline & Apron Maxx RTA & 18.1 & 16.1 & $1,341.2$ & 18.6 & 17.4 & $1,561.1$ \\
\hline & Apron XL & 18.2 & 17.7 & $1,846.3$ & 19.4 & 19.1 & $1,562.3$ \\
\hline & Apron Maxx RTA + Apron XL & 18.6 & 17.5 & $1,407.7$ & 18.9 & 18.5 & $2,086.5$ \\
\hline \multirow[t]{4}{*}{ Elgin 87} & Nontreated Check & 17.5 & 15.9 & $1,547.5$ & 17.9 & 17.3 & $2,613.2$ \\
\hline & Apron Maxx RTA & 18.2 & 17.9 & $1,710.0$ & 19.3 & 18.7 & $2,658.7$ \\
\hline & Apron XL & 19.0 & 18.5 & $1,598.3$ & 18.7 & 18.4 & $2,666.3$ \\
\hline & Apron Maxx RTA + Apron XL & 17.8 & 16.7 & $1,739.9$ & 19.0 & 18.4 & $2,190.6$ \\
\hline \multirow[t]{4}{*}{ Means } & Nontreated Check & 16.5 & 9.5 & 854.3 & 17.2 & 10.5 & $1,507.1$ \\
\hline & Apron Maxx RTA & 17.5 & 12.0 & $1,068.8$ & 18.3 & 13.5 & $1,578.8$ \\
\hline & Apron XL & 18 & 13.4 & $1,261.6$ & 18.3 & 13.7 & $1,756.9$ \\
\hline & Apron Maxx RTA + Apron XL & 18.1 & 12.5 & $1,320.4$ & 18.2 & 14.4 & $1,808.2$ \\
\hline $\operatorname{LSD}^{\mathrm{c}}(P \leq 0.05) \mathrm{C}$ & & $1.04 * *$ & $1.52 * *$ & $363.15^{*}$ & $0.90 * *$ & $1.34 * *$ & NS \\
\hline $\mathrm{LSD}(P \leq 0.05) \mathrm{T}$ & & $0.92 * *$ & $1.35^{* * *}$ & $322.8 * *$ & $0.80 * *$ & $1.20 * *$ & $361.63 * *$ \\
\hline $\mathrm{LSD}(P \leq 0.05) \mathrm{C} \times \mathrm{T}$ & & NS & NS & NS & NS & NS & NS \\
\hline
\end{tabular}

${ }^{a}$ Number of plants per meter at VC growth stage (plant emergence) and R7 growth stage (when all leaves are gone and one pod on main stem has mature pod color.

b Adjusted to $13 \%$ moisture.

${ }^{\mathrm{c}}$ Fisher's protected least significant difference, $* *$ indicates $P<0.01$, and $*$ indicates $P<0.05$. 
plot and seed treatment as the subplot. Each experimental unit consisted of four rows spaced $38 \mathrm{~cm}$ apart, $9.1 \mathrm{~m}$ long with 3-m alleyways between plots. Alleyways were planted with the susceptible cultivar Sloan to serve as an indicator of the total disease level. During 2005, the field was irrigated with a total of $7.3 \mathrm{~cm}$ of water from 6 to 12 June, which coincided with the first trifoliate fully expanded (V1 growth stage, 19) for the 18 May and preemergence for the 2 June plantings. Stand counts were recorded 21 June, 29 June, 12 July, 26 July, 11 August, 23 August, and 21 September 2005 from a 0.9-m section in each row in each plot. Yields were recorded at harvest on 18 October. During 2006, the study was irrigated with $5.3 \mathrm{~cm}$ of water from 14 to 16 June, and stand counts were recorded on 29 June, 17 August, and 10 October. The plots were harvested on 13 October.

South Dakota. The study was planted on 6 June 2003 in Brown County near Groton, SD in a commercial production field with a history of Phytophthora root and stem rot even when cultivars with Rps1a, Rps 1c, or Rps 1k were planted. The soil was a Brookston silty clay loam with $30 \%$ clay content. The study was arranged in a randomized split-plot design with the eight cultivars (Table 1) as the whole plot and seed treatment as the subplot with three replications. The subplots were $4.6 \mathrm{~m}$ long with two rows of each cultivar treated with metalaxyl at $0.94 \mathrm{~g} / \mathrm{kg}$ (Allegiance FL) and two rows nontreated. Rows were spaced $76 \mathrm{~cm}$ apart. Stand counts were recorded from $1 \mathrm{~m}$ of row near the center of the plot on 31 July 2003 when a pod is 5 $\mathrm{mm}$ long on one of the four uppermost nodes of the main stem with a fully developed trifoliate (R3 growth stage, 19). Yields were recorded on 9 October 2003 and adjusted to $13 \%$ moisture.

Wisconsin. The field study was planted on 23 May 2006 at a commercial farm in Racine County. The field is comprised of $30 \%$ clay and has a history of disease caused by $P$. sojae race 3 (vir 1a, 7). Five soybean cultivars were selected and treated with mefenoxam, $3.75 \mathrm{~g}$ a.i. and fludioxonil, $2.5 \mathrm{~g}$ a.i./100 kg seed (Apron Maxx RTA) or left nontreated. Treatments were planted in a complete randomized block design with four replications. Individual plots consisted of six rows spaced $38 \mathrm{~cm}$ apart, $7.7 \mathrm{~m}$ long with 3-m alleyways between blocks. Stand counts were recorded on 15 June from a 1-m section of one row in each plot at the V1 growth stage. Plant mortality was recorded on 15 June as a percentage of dead seedlings per meter of row and as a percentage of dead seedlings per plot on 28 June. Plots were harvested on 10 October and yield adjusted to $13 \%$ grain moisture.

Ontario, Canada. The study was planted at the Agriculture and Agri-Food Canada's Greenhouse and Processing
Crops Research Centre Woodslee Research Farm in Woodslee, Ontario, Canada on 7 June 2004. The Woodslee fields A and B are classified as a Brookston clay-loam soil and were naturally infested with $P$. sojae. The fields were adjacent to the Ontario Soybean Performance "Phytophthora Nursery" which has been used annually in Ontario since 1978 to evaluate the partial resistance of commercial soybean varieties and candidate lines to root rot caused by $P$. sojae. P. sojae isolates from the field study locations contained a complex virulence formula as demonstrated by their ability to infect soybeans with Rps $1 \mathrm{a}, 1 \mathrm{k}, 6$, or 8 as well as additional differentials. In 2004, three seed treatments including mefenoxam, $3.75 \mathrm{~g}$ a.i. and fludioxonil, $2.5 \mathrm{~g}$ a.i./100 kg seed (Apron Maxx RTA); mefenoxam, $3.75 \mathrm{~g}$ a.i. and fludioxonil, $2.5 \mathrm{~g}$

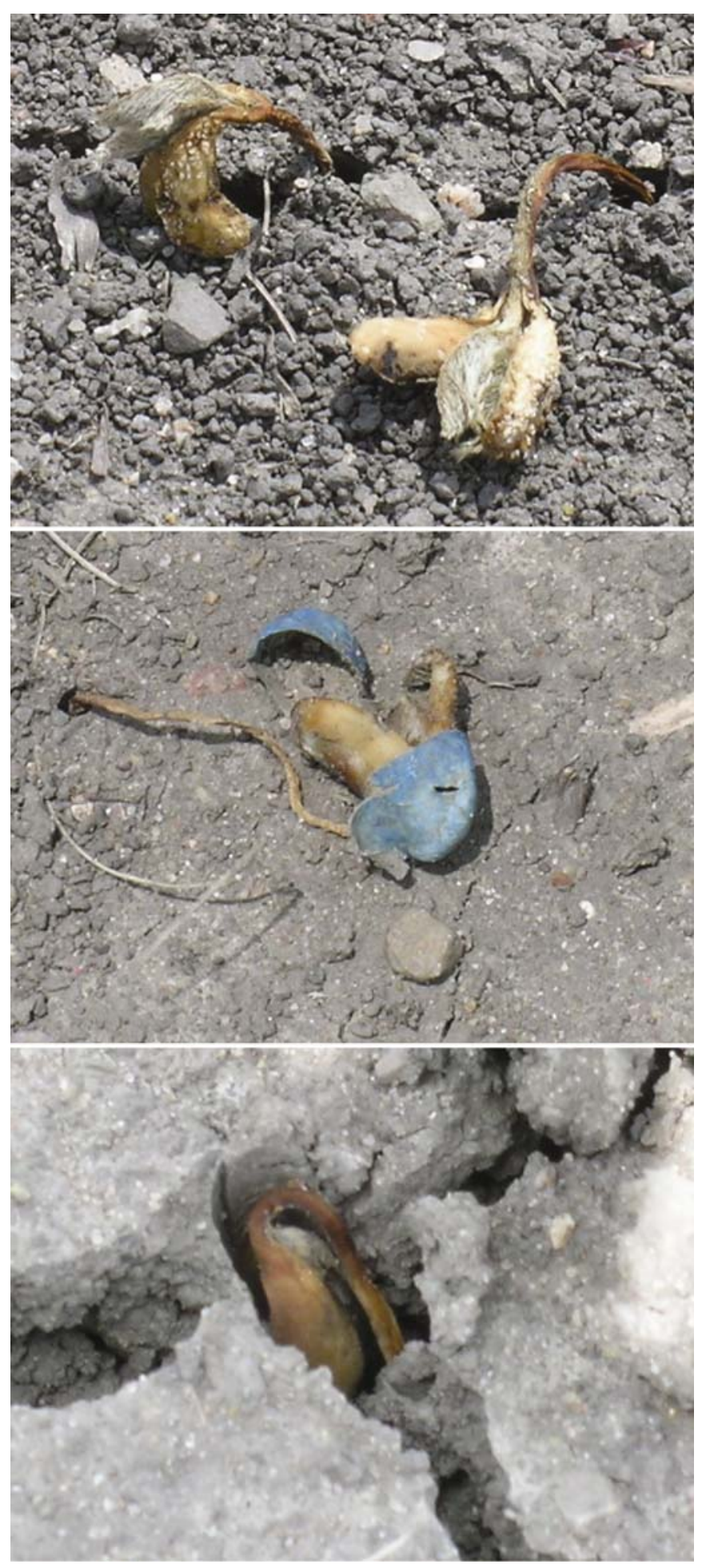

Fig. 2. Soybean seedlings with symptoms of damping-off caused by Phytophthora sojae on both treated and nontreated seed. Note the presence of seed coat above soil surface following germination of seedlings. 
a.i./100 kg seed (Apron Maxx RTA) plus mefenoxam,11.25 g a.i./100 kg (Apron $\mathrm{XL})$ and mefenoxam, $15 \mathrm{~g}$ a.i./100 kg (Apron XL) were evaluated on five cultivars (Table 1) in a randomized complete block design with four replications. Individual plots consisted of four rows spaced $50 \mathrm{~cm}$ apart and $2.5 \mathrm{~m}$ in length with 50 seeds per row. Emergence and final stand counts were recorded from the center two rows on 30 June and 9 August. The center two rows were harvested on 27 October 2004 and yields were adjusted to $13 \%$ moisture.

Statistical analysis. Due to the different cultivars, planting dates, and overall level of disease, each location-year was analyzed separately. For all locations, a factorial or split-plot analysis of variance using PROC GLM (SAS Institute, Cary, NC) was completed. When significant differences were detected for treatment effects, Fishers protected least significant difference (LSD, $P \leq 0.05$ ) was used for mean separations.

\section{RESULTS}

Disease, as measured by the number of seedlings damped-off in the study and reduced germination of nontreated controls, was highest in this study in Ohio (Table 3), South Dakota (Table 4), and Ontario (Table 5). In addition, Albert City,
IA had moderate levels of late-season Phytophthora stem rot based on the overall reduction in plant stand during 2006 (Table 6). Disease was low in the two remaining locations in Iowa (Table 6), as well as locations in Nebraska (Table 7) and Wisconsin (Table 8).

Stands were significantly higher in plots with a seed treatment and when irrigation or rainfall occurred shortly after planting, in Ohio during 2005 and 2006 (Table 3), South Dakota (Table 4), and Ontario (Table 5). In Ohio, when fields were irrigated following planting, yields were 215.0 and $416.6 \mathrm{~kg} / \mathrm{ha}$ higher across the study during 2005 and 2006, respectively (Table 3). A similar trend also occurred in South Dakota, where there was a $289.0 \mathrm{~kg} / \mathrm{ha}$ average increase in yield resulting from the addition of the fungicide seed treatment over nontreated across all cultivars (Table 4). In Ontario, seed treatments increased emergence and final stands in two 2004 trials. Yields were increased significantly by 216.4 to $471.0 \mathrm{~kg} / \mathrm{ha}$ in one trial (Woodslee A) but not in another trial (Woodslee B) during 2004 (Table 5).

In contrast, there were no significant increases in stand or yield consistently across cultivars when seed treatments were applied in Iowa, Nebraska, Wisconsin, or Ohio when the study was irrigated at the V1 growth stage (2005). In Wisconsin, there was an average of $11 \%$ seedling mortality across all fungicide seed treatments and cultivars (Table 8). In Iowa, for some cultivars, final plant stand was either significantly increased or decreased with the addition of the seed treatments. At these three locations in Iowa, as well as $\mathrm{Ne}$ braska, there was little seedling dampingoff (data not shown).

For Iowa, Ohio, and Ontario, the yields of cultivars with high partial resistance combined with or without an Rps gene were significantly higher than cultivars with low partial resistance whether a seed treatment was used or not. In Wisconsin, cultivars with no Rps gene (Croplan RT 2440) or Rps1c (Pioneer 92M40) had significantly higher yields than cultivars with either Rps1a or Rps1k. Damping-off did occur across all cultivars, indicating that the $P$. sojae population that was present in Wisconsin had virulence to all of the Rps genes in the cultivars planted at this location.

\section{DISCUSSION}

Environment plays a key role in the development of Phytophthora seedling blight and root and stem rot in soybeans. P. sojae is a water mold, and for the infective zoospores to develop, saturated soils are necessary. Therefore, the length of time for an infection period is the time that the soils

Table 6. Stand and yield of soybeans with different levels of resistance to Phytophthora sojae treated with mefenoxam, $15.0 \mathrm{~g}$ a.i./100 kg of seed (Apron $\mathrm{XL}$ ), mefenoxam, $11.25 \mathrm{~g}$ a.i./100 $\mathrm{kg}$ of seed (Apron XL) plus mefenoxam, $3.75 \mathrm{~g}$ a.i. and fludioxonil, $2.5 \mathrm{~g}$ a.i./100 kg seed (Apron Maxx RTA) or nontreated in three locations in Iowa in 2005 at Eddyville and 2006 at Albert City and Albion

\begin{tabular}{|c|c|c|c|c|c|c|c|c|c|c|}
\hline \multirow[b]{2}{*}{$\begin{array}{l}\text { Cultivar } \\
\text { (C) }\end{array}$} & \multirow[b]{2}{*}{$\begin{array}{c}\text { Seed treatment } \\
\text { (T) }\end{array}$} & \multicolumn{3}{|c|}{ Eddyville } & \multicolumn{3}{|c|}{ Albert City } & \multicolumn{3}{|c|}{ Albion } \\
\hline & & $\begin{array}{c}\text { Stand } \\
\mathrm{V}^{\mathrm{a}}\end{array}$ & $\begin{array}{c}\text { Final } \\
\text { stand }^{\mathrm{a}}\end{array}$ & $\begin{array}{c}\text { Yield } \\
(\mathbf{k g} / \mathbf{h a})^{b}\end{array}$ & $\begin{array}{c}\text { Stand } \\
\text { V2 }\end{array}$ & $\begin{array}{l}\text { Final } \\
\text { stand }\end{array}$ & $\begin{array}{c}\text { Yield } \\
\text { (kg/ha) }\end{array}$ & $\begin{array}{l}\text { Stand } \\
\text { V2 }\end{array}$ & $\begin{array}{l}\text { Final } \\
\text { stand }\end{array}$ & $\begin{array}{c}\text { Yield } \\
(\mathbf{k g} / \mathbf{h a})\end{array}$ \\
\hline Sloan & $\begin{array}{l}\text { None } \\
\text { Apron XL } \\
\text { Apron Maxx + Apron XL }\end{array}$ & $\begin{array}{l}50.0 \\
52.8 \\
47.5\end{array}$ & $\begin{array}{l}36.4 \\
34.4 \\
32.4\end{array}$ & $\begin{array}{l}4,019.9 \\
3,901.6 \\
3,886.8\end{array}$ & $\begin{array}{l}23.8 \\
24.4 \\
23.5\end{array}$ & $\begin{array}{l}21.5 \\
23.4 \\
21.5\end{array}$ & $\begin{array}{l}2,983.7 \\
3,303.6 \\
3,396.3\end{array}$ & $\begin{array}{l}55.0 \\
62.3 \\
56.8\end{array}$ & $\begin{array}{l}56.2 \\
60.3 \\
57.3\end{array}$ & $\begin{array}{l}2,731.7 \\
2,958.1 \\
2,770\end{array}$ \\
\hline Williams & $\begin{array}{l}\text { None } \\
\text { Apron XL } \\
\text { Apron Maxx + Apron XL }\end{array}$ & $\begin{array}{l}- \\
- \\
-\end{array}$ & $\begin{array}{l}- \\
- \\
-\end{array}$ & $\begin{array}{l}- \\
- \\
-\end{array}$ & $\begin{array}{l}29.3 \\
27.6 \\
27.0\end{array}$ & $\begin{array}{l}23.8 \\
25.7 \\
20.4\end{array}$ & $\begin{array}{l}2,823.1 \\
2,915.1 \\
2,339.1\end{array}$ & $\begin{array}{l}49.0 \\
44.5 \\
54.5\end{array}$ & $\begin{array}{l}47.0 \\
45.9 \\
48.4\end{array}$ & $\begin{array}{l}2,744.4 \\
2,696.7 \\
2,628.9\end{array}$ \\
\hline S31-V3 & $\begin{array}{l}\text { None } \\
\text { Apron XL } \\
\text { Apron Maxx + Apron XL }\end{array}$ & $\begin{array}{l}52.4 \\
46.8 \\
47.5\end{array}$ & $\begin{array}{l}46.4 \\
36.4 \\
37.3\end{array}$ & $\begin{array}{l}5,079.6 \\
5,097.1 \\
5,230.2\end{array}$ & $\begin{array}{l}- \\
- \\
-\end{array}$ & $\begin{array}{l}- \\
- \\
-\end{array}$ & $\begin{array}{l}- \\
- \\
-\end{array}$ & $\begin{array}{l}- \\
- \\
-\end{array}$ & $\begin{array}{l}- \\
- \\
-\end{array}$ & $\begin{array}{l}- \\
- \\
-\end{array}$ \\
\hline Stine 2402 & $\begin{array}{l}\text { None } \\
\text { Apron XL } \\
\text { Apron Maxx + Apron XL }\end{array}$ & $\begin{array}{l}49.8 \\
48.3 \\
40.3\end{array}$ & $\begin{array}{l}38.2 \\
42.4 \\
32.2\end{array}$ & $\begin{array}{l}4,145.6 \\
4,277.3 \\
3,829.1\end{array}$ & $\begin{array}{l}16.7 \\
18.0 \\
27.8\end{array}$ & $\begin{array}{l}16.2 \\
16.9 \\
19.9\end{array}$ & $\begin{array}{l}4,230.2 \\
4,140.2 \\
4,302.8\end{array}$ & $\begin{array}{l}57.2 \\
57.4 \\
57.7\end{array}$ & $\begin{array}{l}57.4 \\
50.5 \\
57.5\end{array}$ & $\begin{array}{l}4,116 \\
4,118 \\
4,192.6\end{array}$ \\
\hline S27-T7 & $\begin{array}{l}\text { None } \\
\text { Apron XL } \\
\text { Apron Maxx + Apron XL }\end{array}$ & $\begin{array}{l}51.8 \\
46.0 \\
44.8\end{array}$ & $\begin{array}{l}40.0 \\
38.5 \\
36.0\end{array}$ & $\begin{array}{l}4,949.3 \\
4,892.8 \\
4,676.4\end{array}$ & $\begin{array}{l}24.3 \\
24.8 \\
26.3\end{array}$ & $\begin{array}{l}20.4 \\
17.7 \\
22.2\end{array}$ & $\begin{array}{l}4,437.2 \\
4,364.6 \\
4,453.3\end{array}$ & $\begin{array}{l}59.2 \\
52.7 \\
58.0\end{array}$ & $\begin{array}{l}57.3 \\
52.3 \\
60.0\end{array}$ & $\begin{array}{l}3,888.9 \\
3,781.3 \\
3,837.1\end{array}$ \\
\hline 2834RR & $\begin{array}{l}\text { None } \\
\text { Apron XL } \\
\text { Apron Maxx + Apron XL }\end{array}$ & $\begin{array}{l}49.3 \\
50.0 \\
48.0\end{array}$ & $\begin{array}{l}35.5 \\
40.0 \\
39.5\end{array}$ & $\begin{array}{l}5,228.2 \\
5,245.0 \\
5,191.9\end{array}$ & $\begin{array}{l}31.0 \\
25.3 \\
26.8\end{array}$ & $\begin{array}{l}28.7 \\
22.5 \\
23.4\end{array}$ & $\begin{array}{l}4,497 \\
4,590 \\
4,278.6\end{array}$ & $\begin{array}{l}53.0 \\
53.3 \\
52.5\end{array}$ & $\begin{array}{l}47.3 \\
46.7 \\
43.5\end{array}$ & $\begin{array}{l}3,966.1 \\
4,013.2 \\
4,182.5\end{array}$ \\
\hline Archer & $\begin{array}{l}\text { None } \\
\text { Apron XL } \\
\text { Apron Maxx + Apron XL }\end{array}$ & $\begin{array}{l}46.0 \\
51.8 \\
51.3\end{array}$ & $\begin{array}{l}32.4 \\
40.8 \\
34.5\end{array}$ & $\begin{array}{l}3,171.4 \\
3,225.1 \\
2,855.6\end{array}$ & $\begin{array}{l}30.5 \\
25.0 \\
27.0\end{array}$ & $\begin{array}{l}26.8 \\
29.2 \\
24.9\end{array}$ & $\begin{array}{l}3,480.4 \\
3,258.7 \\
3,292.3\end{array}$ & $\begin{array}{l}40.5 \\
34.2 \\
40.8\end{array}$ & $\begin{array}{l}46.4 \\
37.4 \\
35.2\end{array}$ & $\begin{array}{l}3,299.0 \\
3,332.6 \\
3,352.8\end{array}$ \\
\hline Means & $\begin{array}{l}\text { None } \\
\text { Apron XL } \\
\text { Apron Maxx + Apron XL }\end{array}$ & $\begin{array}{l}49.9 \\
49.3 \\
46.6\end{array}$ & $\begin{array}{l}38.2 \\
38.7 \\
35.3\end{array}$ & $\begin{array}{l}4,432.3 \\
4,439.8 \\
4,278.3\end{array}$ & $\begin{array}{l}25.9 \\
24.2 \\
26.4\end{array}$ & $\begin{array}{l}22.9 \\
22.6 \\
22.1\end{array}$ & $\begin{array}{l}3,741.9 \\
3,762.0 \\
3,677.1\end{array}$ & $\begin{array}{l}52.3 \\
50.7 \\
53.4\end{array}$ & $\begin{array}{l}51.9 \\
48.9 \\
50.3\end{array}$ & $\begin{array}{l}3,457.7 \\
3,483.3 \\
3,494.0\end{array}$ \\
\hline $\begin{array}{l}\operatorname{LSD}^{\mathrm{c}}(P<0 \\
\operatorname{LSD}(P<0 \\
\operatorname{LSD}(P<0\end{array}$ & $\begin{array}{l}\text { 5) } \mathrm{C} \\
\mathrm{T} \\
\mathrm{T} \times \mathrm{T}\end{array}$ & $\begin{array}{l}4.6^{*} \\
3.3^{*} \\
8.0^{*}\end{array}$ & $\begin{array}{l}6.6^{*} \\
4.0^{*} \\
9.7^{*}\end{array}$ & $\begin{array}{l}264.6^{* *} \\
187.1^{*} \\
458.2^{* *}\end{array}$ & $\begin{array}{l}4.6^{*} \\
\mathrm{NS} \\
8.0^{*}\end{array}$ & $\begin{array}{l}3.1^{*} \\
\mathrm{NS} \\
5.3 *\end{array}$ & $\begin{array}{l}285.6^{* *} \\
\mathrm{NS} \\
494.6^{*}\end{array}$ & $\begin{array}{l}6.3 * * \\
\text { NS } \\
11.0 *\end{array}$ & $\begin{array}{l}5.9 * * \\
\mathrm{NS} \\
10.2 *\end{array}$ & $\begin{array}{l}581.7 * * \\
\text { NS } \\
1,007.6^{*}\end{array}$ \\
\hline
\end{tabular}

${ }^{a}$ Number of plants in $1 \mathrm{~m}$ of row with counts made in each of two center rows. V2 = two fully developed trifoliate leaves that have unrolled.

${ }^{\mathrm{b}}$ Adjusted to $13 \%$ moisture.

${ }^{\mathrm{c}}$ Fisher's protected least significant difference, $* *$ indicates $P<0.01$, and $*$ indicates $P<0.05$. 
are saturated. Seed treatment compounds have limited effective period. When a soybean seed germinates, the seed coat is pushed out of the ground and remains on the cotyledons (Fig. 2); thus, this period of seed protection is further restricted in soybean. This study provides some of the first substantiated evidence where the seed treatment failed to provide any protection for damping-off (Wisconsin).

The benefit of seed treatment was highly variable across all locations. The efficacy of seed treatments was realized primarily when heavy rains occurred shortly after planting (a week or two). This was demonstrated in Ontario during the 2004 season, when $6.7 \mathrm{~cm}$ of rain fell within 10 days of planting; in South Dakota during 2003, when $14.4 \mathrm{~cm}$ of rain fell within 20 days of planting; and in Ohio, where the fields were irrigated with 7.3 and $5.3 \mathrm{~cm}$ of water shortly after planting. There were no negative effects of the seed treatments on yield, as in locations where there was no net gain in yield with seed treatments, no significant reductions in yield occurred. Environment by seed treatment differences in soybeans have been reported previously $(5,6,13)$. Bradley $(5)$ reported that 4 out of 12 environments had higher yields with seed treatment than without. This difference in effect was proposed to be related to low soil temperatures $\left(<15^{\circ} \mathrm{C}\right)$ and high soil moisture conditions at planting, as well as a different pathogen complex present in any particular field (5). Guy et al. (13) found the highest benefit with metalaxyl applications was achieved when there was a high proportion of $P$. sojae in the field. In addition, in fields in Ohio where stand establishment was a concern even with metalaxyl or mefenoxam treated seed, Pythium spp., which were insensitive to these compounds, were identified $(7,9)$. More surveys are needed across the northcentral region to identify the soilborne pathogen complex that may be affecting soybeans.
In locations where substantial disease occurred, there were large differences in yield among the cultivars with different levels of partial resistance. Cultivars with low partial resistance had significantly lower yields than those with higher levels of partial resistance regardless of the presence of an Rps gene. These results support an earlier finding by Dorrance et al. (12) in which cultivars with high partial resistance had consistently higher yields across locations. As the diversity and expansion of $P$. sojae continues to increase across the region, the partial resistance component of the resistance package will become increasingly more important.

In this study, both environment and pathogen inoculum density may have played a role in achieving a positive yield response when a seed treatment was used. Fields where soybeans may see the greatest benefit of utilizing these integrated management strategies, namely partial resistance and fungicide seed treatment, will need to be identified on an individual or region-wide basis. Furthermore, characterizing the soilborne pathogen complex that is limiting soybean production would greatly benefit appropriate disease management choices. This was emphasized with the development of damping-off of seedlings from treated seed in Wisconsin.

\section{ACKNOWLEDGMENTS}

We wish to thank the long list of students and research associates who were involved in these studies as well as producers who cooperated with sampling and provided land for these studies. A. U. Tenuta and A. E. Dorrance are especially grateful to David Hooker for assistance with statistical analysis. We are especially grateful for funding from the North Central Soybean Research Program, state soybean boards, and the Ontario Soybean Growers for providing funding for these research projects outlined in this paper. Salaries and research support were provided by state and federal funds appropriated to the Ohio Agricultural Research and Development Center, the Ohio State University, University of Nebraska, University of Illinois, Iowa State University, South Dakota State University, University of Minnesota, and University of Wisconsin.

Table 8. Comparison of soybean cultivars that differ in resistance combinations to Phytophthora sojae and seed treated with mefenoxam, $3.75 \mathrm{~g}$ a.i. and fludioxonil, $2.5 \mathrm{~g}$ a.i./100 $\mathrm{kg}$ (ApronMaxx) or nontreated in Wisconsin during 2005

\begin{tabular}{lcccc}
\hline Cultivar (C) & $\begin{array}{c}\text { Seed treatment } \\
(\mathbf{T})\end{array}$ & $\begin{array}{c}\text { Plant population } \\
(\text { plants/m) }\end{array}$ & $\begin{array}{c}\text { Percent } \\
\text { damping-off }\end{array}$ & $\begin{array}{c}\text { Yield } \\
(\mathbf{k g} / \mathbf{h a})\end{array}$ \\
\hline Croplan RT 2440 & Nontreated & 18 & 12 & $5,476.8$ \\
& ApronMaxx & 14 & 8 & $5,745.6$ \\
Sturdy & Nontreated & 10 & 6 & $\mathrm{NA}^{\mathrm{b}}$ \\
& ApronMaxx & 13 & 21 & $\mathrm{NA}^{-}$ \\
Pioneer 92M40 & Nontreated & 11 & 3 & $5,006.4$ \\
& ApronMaxx & 14 & 9 & $5,597.8$ \\
NK S24-K4 & Nontreated & 14 & 2 & $4,912.3$ \\
& ApronMaxx & 17 & 4 & $4,132.8$ \\
Asgrow AG2403 & Nontreated & 12 & 21 & $4,576.3$ \\
& ApronMaxx & 13 & 23 & $4,368.0$ \\
Means & Nontreated & 13 & 9 & $5,006.4$ \\
& ApronMaxx & 14 & 12 & $4,993.0$ \\
LSD $(P \leq 0.05)$ C & & $\mathrm{NS}$ & $\mathrm{NS}$ & $564.5^{*}$ \\
LSD $(P \leq 0.05) \mathrm{T}$ & & $\mathrm{NS}$ & $\mathrm{NS}$ & $\mathrm{NS}$ \\
LSD $(P \leq 0.05) \mathrm{C} \times \mathrm{T}$ & & $\mathrm{NS}$ & $\mathrm{NS}$ & $\mathrm{NS}$ \\
\hline
\end{tabular}

${ }^{\text {a }}$ Stand counts were recorded at the VI growth stage.

b Yields of cultivar Sturdy (conventional cultivar) were not included due to application of glyphosate.

${ }^{\mathrm{c}}$ Fisher's protected least significant difference. * indicates $P=0.05$.

Table 7. Comparison of soybean cultivars with different resistance combinations to Phytophthora sojae and seed treated with mefenoxam, $3.75 \mathrm{~g}$ a.i. and fludioxonil, $2.5 \mathrm{~g}$ a.i./100 $\mathrm{kg}$ seed plus mefenoxam, $11.25 \mathrm{~g}$ a.i./100 $\mathrm{kg}$ seed (ApronMaxx plus Apron XL) or nontreated in Nebraska during 2004 and 2005

\begin{tabular}{|c|c|c|c|c|c|c|c|}
\hline \multirow[b]{2}{*}{ Cultivar (C) } & \multirow[b]{2}{*}{ Seed treatment $(T)$} & \multicolumn{3}{|c|}{2004} & \multicolumn{3}{|c|}{2005} \\
\hline & & $\begin{array}{c}\text { Stand } \\
\text { V2 }^{\mathrm{a}}\end{array}$ & $\begin{array}{l}\text { Harvest } \\
\text { stand }^{\mathbf{a}}\end{array}$ & $\underset{(\mathrm{kg} / \mathrm{ha})^{\mathrm{b}}}{\text { Yield }}$ & $\begin{array}{l}\text { Stand } \\
\text { R1 }\end{array}$ & $\begin{array}{l}\text { Final } \\
\text { stand }\end{array}$ & $\begin{array}{c}\text { Yield } \\
(\mathbf{k g} / \mathrm{ha})\end{array}$ \\
\hline Asgrow AG2703 & $\begin{array}{l}\text { Nontreated } \\
\text { ApronMaxx plus Apron XL }\end{array}$ & $\begin{array}{l}27.2 \\
28.6\end{array}$ & $\begin{array}{l}22.0 \\
21.1\end{array}$ & $\begin{array}{l}3,064.3 \\
3,131.5\end{array}$ & $\begin{array}{l}25.3 \\
25.6\end{array}$ & $\begin{array}{l}14.8 \\
13.1\end{array}$ & $\begin{array}{l}2,473.0 \\
2,499.8\end{array}$ \\
\hline Garst 2903 RR & $\begin{array}{l}\text { Nontreated } \\
\text { ApronMaxx plus Apron XL }\end{array}$ & $\begin{array}{l}29.5 \\
27.5\end{array}$ & $\begin{array}{l}21.4 \\
23.2\end{array}$ & $\begin{array}{l}3,151.7 \\
3,138.2\end{array}$ & $\begin{array}{l}25.3 \\
24.9\end{array}$ & $\begin{array}{l}15.7 \\
14.9\end{array}$ & $\begin{array}{l}2,681.3 \\
2,540.2\end{array}$ \\
\hline Garst 3083 RR & $\begin{array}{l}\text { Nontreated } \\
\text { ApronMaxx plus Apron XL }\end{array}$ & $\begin{array}{l}29.8 \\
28.6\end{array}$ & $\begin{array}{l}22.5 \\
21.2\end{array}$ & $\begin{array}{l}3,192.0 \\
3,097.9\end{array}$ & $\begin{array}{l}24.5 \\
22.9\end{array}$ & $\begin{array}{l}18.8 \\
14.8\end{array}$ & $\begin{array}{l}2,607.4 \\
2,620.8\end{array}$ \\
\hline Means & $\begin{array}{l}\text { Nontreated } \\
\text { ApronMaxx plus Apron XL }\end{array}$ & $\begin{array}{l}28.8 \\
28.2\end{array}$ & $\begin{array}{l}22.0 \\
21.8\end{array}$ & $\begin{array}{l}3,136.0 \\
3,122.5\end{array}$ & $\begin{array}{l}25.0 \\
24.5\end{array}$ & $\begin{array}{l}16.4 \\
14.3\end{array}$ & $\begin{array}{l}2,587.2 \\
2,553.6\end{array}$ \\
\hline $\begin{array}{l}\operatorname{LSD}^{\mathrm{c}}(P \leq 0.05) \mathrm{C} \\
\mathrm{LSD}(P \leq 0.05) \mathrm{T} \\
\operatorname{LSD}(P \leq 0.05) \mathrm{C} \times \mathrm{T}\end{array}$ & - & $\begin{array}{l}\text { NS } \\
\text { NS } \\
\text { NS }\end{array}$ & $\begin{array}{l}\text { NS } \\
\text { NS } \\
\text { NS }\end{array}$ & $\begin{array}{l}\text { NS } \\
\text { NS } \\
\text { NS }\end{array}$ & $\begin{array}{l}\text { NS } \\
\text { NS } \\
\text { NS }\end{array}$ & $\begin{array}{l}\text { NS } \\
\text { NS } \\
\text { NS }\end{array}$ & $\begin{array}{l}\text { NS } \\
\text { NS } \\
\text { NS }\end{array}$ \\
\hline
\end{tabular}

a Number of plants per meter of row with counts made in each of two center rows six times for each plot at the V2 growth stage (when plants have two fully developed trifoliate leaves).

${ }^{\mathrm{b}}$ Adjusted to $13 \%$ moisture.

${ }^{c}$ Fisher's protected least significant difference. 
Salaries and research support for Ontario was provided by the Agriculture and Agri-Food Canada, the Ontario Ministry of Agriculture, Food and Rural Affairs (OMAFRA), and the University of Guelph, Ridgetown Campus. Mention of trade names or commercial products in this publication is solely for the purpose of providing specific information and does not imply recommendation or endorsement by the these Universities.

\section{LITERATURE CITED}

1. Abney, T. S., Melgar, J. C., Richards, T. L. Scott, D. H., Grogan, J., and Young, J. 1997. New races of Phytophthora sojae with Rps1-d virulence. Plant Dis. 81:653-655.

2. Beuerlein, J. E., St. Martin, S. K., Dorrance, A. E., and Van Diest, C. D. K. 1999. Ohio Soybean Performance Trials 1999. OSU Hortic. Crop Sci. Dep. Ser. 212.

3. Beuerlein, J. E., St. Martin, S. K., Dorrance, A. E., and Van Diest, C. D. K. 2001. Ohio Soybean Performance Trials 2001. OSU Hortic. Crop Sci. Dep. Ser. 212.

4. Beuerlein, J. E., St. Martin, S. K., Dorrance, A. E., and Van Diest, C. D. K. 2003. Ohio Soybean Performance Trials 2003. OSU Hortic. Crop Sci. Dep. Ser. 212.

5. Bradley, C. A. 2008. Effect of fungicide seed treatments on stand establishment, seedling disease, and yield of soybean in North Dakota. Plant Dis. 92:120-125.

6. Bradley, C. A., Wax, L. M., Ebelhar, S. A., Bollero, G. A., and Pedersen, W. L. 2001. The effect of fungicide seed protectants, seeding rates, and reduced rates of herbicides on no till soybean. Crop Prot. 20:615-622.

7. Broders, K. D., Lipps, P. E., Paul, P. A., and
Dorrance, A. E. 2007. Characterization of $P y$ thium spp. associated with corn and soybean seed and seedling disease in Ohio. Plant Dis. 91:727-735.

8. Dorrance, A. E., Berry S. A., Anderson, T. R., and Meharg, C. 2008. Isolation, storage, pathotype characterization, and evaluation of resistance for Phytophthora sojae in soybean. Online. Plant Health Progress doi:10.1094/ PHP-2008-01XX-01-DG

9. Dorrance, A. E., Berry, S. A., Bowen, P., and Lipps, P. E. 2004. Characterization of Pythium spp. from three Ohio fields for pathogenicity on corn and soybean and metalaxyl sensitivity. Plant Health Progress doi:10.1094/PHP-20040202-01-RS.

10. Dorrance, A. E., and McClure, S. A. 2001. Beneficial effects of fungicide seed treatments for soybean cultivars with partial resistance to Phytophthora sojae. Plant Dis. 85:1063-1068.

11. Dorrance, A. E., McClure, S. A., and deSilva, A. 2003. Pathogenic diversity of Phytophthora sojae in Ohio soybean fields. Plant Dis. 87:139-146.

12. Dorrance, A. E., McClure, S. A., and St. Martin, S. K. 2003. Effect of partial resistance on Phytophthora stem rot incidence and yield of soybean in Ohio. Plant Dis. 87:308-312.

13. Guy, S. O., Oplinger, E. S., and Grau, C. R. 1989. Soybean cultivar response to metalaxyl applied in furrow and as a seed treatment. Agron. J. 81:529-532.

14. Jackson, T. A., Kirkpatrick, T. L., and Rupe, J. C. 2004. Races of Phytophthora sojae in Arkansas fields and their effects on commonly grown soybean cultivars. Plant Dis. 88:345351.
15. Kaitany, R. C., Hart, L. P., and Safir, G. R. 2001. Virulence composition of Phytophthora sojae in Michigan. Plant Dis. 85:1103-1106.

16. Kurle, J. E., and El Araby, E. M. 2001. Chang ing composition of Phytophthora sojae races in Minnesota soils. (Abstr.) Phytopathology 91:S51

17. Malvick, D. K., and Grunden, E. 2004. Traits of soybean-infecting Phytophthora populations from Illinois agricultural fields. Plant Dis. 88:1139-1145.

18. Nelson, B. D., Mallik, I., McEwen, D., and Christianson, T. 2008. Pathotypes, distribution, and metalaxyl sensitivity of Phytophthora sojae from North Dakota. Plant Dis. 92:10621066.

19. Pedersen, P. 2004. Soybean growth and development. Iowa State Univ. Ext. Bull. PM1945, Ames, IA.

20. Schmitthenner, A. F. 1985. Problems and progress in control of Phytophthora root rot of soybean. Plant Dis. 69:362-368.

21. Schmitthenner, A. F., and Bhat, R. G. 1994. Useful methods for studying Phytophthora in the laboratory. OARDC Spec. Circ. 143. Ohio State University, Wooster.

22. Workneh, F., Tylka, G. L., Yang, X. B. Faghihi, J., and Ferris, J. M. 1999. Regiona assessment of soybean brown stem rot, Phytophthora sojae, and Heterodera glycines using area-frame sampling: Prevalence and effects of tillage. Phytopathology 89:204-211.

23. Workneh, F., Yang, X. B., and Tylka, G. L. 1999. Soybean brown stem rot, Phytophthora sojae, and Heterodera glycines affected by soil texture and tillage relations. Phytopathology 89:844-850. 